\section{Identification of Lung Inflammation- Related Elevation of Acylamino Acid Releasing Enzyme (APEH) Activity Using an Enzymomics Approach}

\author{
Toru Komatsu, ${ }^{*, a, b}$ Kentaro Yoshioka, ${ }^{a}$ \\ Kenjiro Hanaoka, ${ }^{a}$ Takuya Terai,${ }^{a, \dagger}$ Tasuku Ueno, ${ }^{a}$ \\ Tetsuo Nagano, ${ }^{c}$ and Yasuteru Urano*,a,d,e \\ ${ }^{a}$ Graduate School of Pharmaceutical Sciences, The University \\ of Tokyo; 7-3-1 Hongo, Bunkyo-ku, Tokyo 113-0033, Japan: \\ ${ }^{b}$ Precursory Research for Embryonic Science and Technology \\ (PRESTO) Investigator, Japan Science and Technology Agency \\ (JST); 4-1-8 Honcho, Kawaguchi, Saitama 332-0012, Japan: \\ ${ }^{c}$ Drug Discovery Initiative, The University of Tokyo; 7-3-1 \\ Hongo, Bunkyo-ku, Tokyo 113-0033, Japan: ${ }^{d}$ Graduate School \\ of Medicine, The University of Tokyo; 7-3-1 Hongo, Bunkyo-ku, \\ Tokyo 113-0033, Japan: and ${ }^{e}$ Core Research for Evolutional \\ Science and Technology (CREST) Investigator, Japan Agency for \\ Medical Research and Development (AMED); 1-7-1 Otemachi, \\ Chiyoda-ku, Tokyo 100-0004, Japan.
}

Received July 4, 2016; accepted August 8, 2016

Disease-associated alterations of enzymatic functions are potentially useful as disease biomarkers, and here we show that an enzymomics (omics of active enzymes) approach, in which enzymatic activities are screened with panels of substrates, can be an effective way to identify such alterations. In the present study, we used a panel of fluorogenic substrates to search for altered enzyme activities in bronchoalveolar lavage fluid (BALF) from a mouse model of lung inflammation. We found that acylamino acid releasing enzyme (APEH) activity was highly elevated, apparently reflecting the increased population of immune cells in the inflamed lung.

Key words chemical biology; fluorescent probe; enzymomics; biomarker; lung inflammation

Cellular functions are mediated by various enzymes, and altered enzymatic functions are often observed during disease onset and progression. Such changes can be helpful for clinical diagnosis and monitoring, and therefore there is great interest in the discovery of novel biomarker candidates. Various types of omics studies (e.g., proteomics, metabolomics) have been used to find biomarkers, but altered enzymatic activity is not always observable with widely used omics platforms. ${ }^{1,2)}$ For example, changes in protein expression level are not always reflected in functional activity, since protein functions are regulated dynamically by multiple factors, including posttranslational modifications, protein-protein interactions, and intrinsic inhibitors. ${ }^{1)}$ Since enzymatic activities in bio-fluids are often measured for diagnostic purposes (e.g., alkaline phosphatases ${ }^{3-5}$ and gamma-glutamyl transferases ${ }^{6-8)}$ ), a better strategy might be to directly screen for altered enzymatic activities in those bio-samples. This approach can be termed enzymomics (omics of active enzymes).

${ }^{\dagger}$ Present address: Graduate School of Science and Engineering, Saitama University; 255 Shimo-Okubo, Sakura-ku, Saitama 338-8570, Japan.
For this purpose, two key technologies are required: firstly, a method to simultaneously monitor multiple enzymatic activities towards a range of substrates, and secondly, a method to identify target proteins exhibiting activities of interest. In this study, we developed a panel of fluorogenic substrates to read out the enzymatic activities of various peptidases, and used it to search for altered enzymatic activities in bronchoalveolar lavage fluid (BALF) from a mouse model of lung inflammation induced by lipopolysaccharide (LPS) and formyl peptide formyl-methionyl-leucyl-phenylalanine (fMLF) (Fig. 1). We found that one of the substrates showed a strongly enhanced fluorescence signal in inflammatory BALF. We then identified the enzyme mediating this activity by means of our recently developed diced electrophoresis gel (DEG) assay. In DEG assay, enzymatic activities are detected after two-dimensional native electrophoresis-based separation of the proteome, and the target protein exhibiting the activity is identified by protein identifying technologies like LC-MS/MS. ${ }^{9-11)}$

BALF is already used in diagnosis of airway diseases, and elastase is well established as one of the biomarkers of lung inflammation. ${ }^{12,13)}$ Increased elastase activity in BALF is due to the increase of immune cells, especially neutrophils, in response to inflammation. ${ }^{14)}$ However, monitoring elastase activity is not an ideal platform for diagnosis, since the activity is known to be affected by intrinsic inhibitors present in BALF and sometimes the degree of activation of the enzyme is not sufficiently high for reliable diagnosis. ${ }^{15,16)}$ Therefore, we set out to find a novel biomarker using a newly developed panel of fluorogenic probes. We focused on aminopeptidase and dipeptidyl peptidase-like activities, because they are less susceptible to intrinsic inhibitors than proteases such as elastases, matrix metalloproteinase (MMPs), and cathepsins. ${ }^{17-19)} \mathrm{We}$ prepared a library of amides based on the 7-amino-4-methylcoumarin (AMC) fluorophore. Protection of the 7-amino group quenches the fluorescence, and hydrolysis releases fluorescent AMC. ${ }^{10,20-22)}$ Our panel of probes consisted mainly of peptidase substrates with relatively short reactive groups (Fig. 2), and included some probes for uncharacterized hydrolases. Elastase activity was monitored with MeO-Suc-Ala-Ala-ProIle-AMC (MeO-SucAAPI-AMC) as a positive control.

Among the fluorogenic probes tested, several showed different responses under inflammatory and control conditions (Fig. 3). Among them, formyl-methionyl-AMC (fMet-AMC) showed a markedly increased fluorescence signal in inflammatory BALF.

The signal intensity and the activation ratio (inflammation/ control) were both much higher than those in the case of elastase, used as the positive control, so we considered that this activity would be potentially useful as a novel biomarker of lung inflammation. Therefore, we set out to identify the target protein exhibiting this activity. Fortunately, we have previously shown that fMet-AMC is metabolized by acylamino acid releasing enzyme (APEH) in mouse liver lysate, ${ }^{11)}$ so it seemed plausible that the same enzyme mediates this activity in inflammatory BALF. In order to test this idea, we performed 2-dimensional native polyacrylamide gel electrophoresis (PAGE)-based separation of the BALF and characterization of the target enzyme by means of DEG assay. ${ }^{9-11)}$ DEG assay 


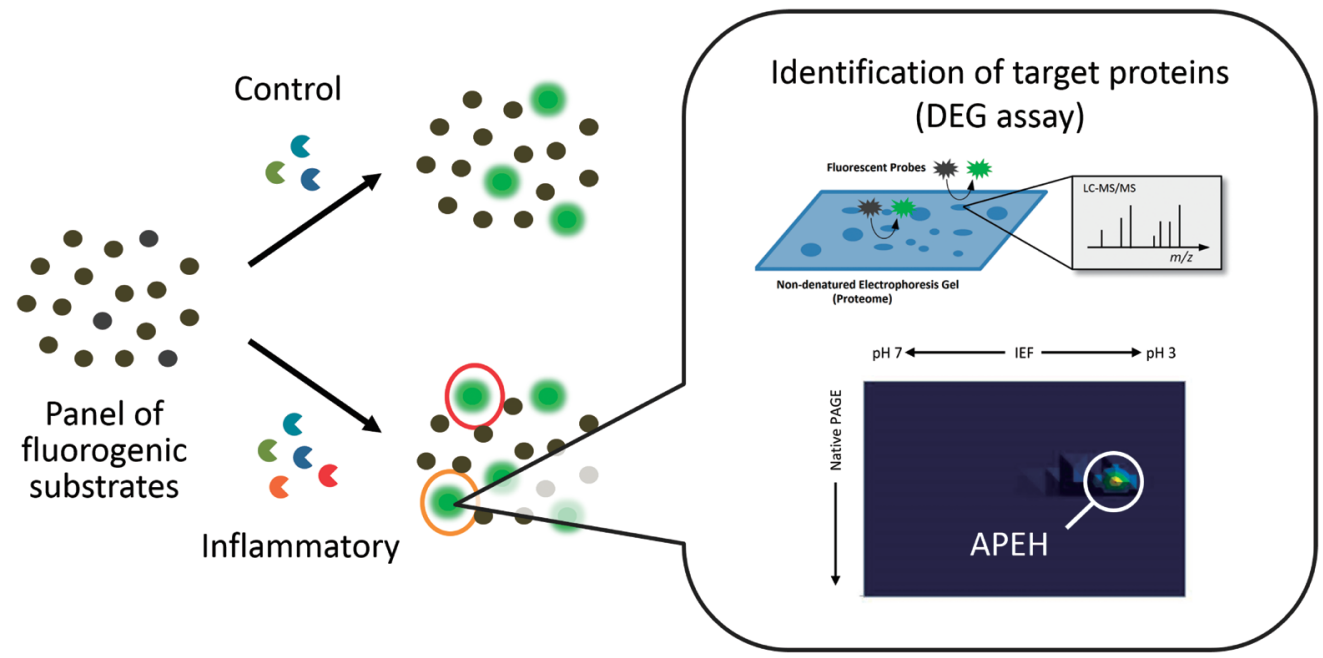

Fig. 1. Enzymomics Study to Identify Lung Inflammation-Specific Enzymatic Activities in BALF<smiles>Cc1cc(=O)oc2cc(NC=O)ccc12</smiles>
Formyl-AMC<smiles>Cc1cc(=O)oc2cc(NC(=O)C(C)N)ccc12</smiles>
Ala-AMC<smiles>Cc1cc(=O)oc2cc(NC(=O)C(Cc3ccccc3)NC(=O)C(NC(=O)C(CC(C)C)NC(=O)C(CC(C)C)NC(=O)CCC(=O)O)C(C)C)ccc12</smiles>

SUCLLVY-AMC

Fig. 2. Structures of Fluorogenic Substrates Used in This Study

Preparation of these compounds has been reported in the literature. ${ }^{10,20-22)}$

is an improved form of zymography, in which the electrophoresis gel is diced into small pieces that are separately loaded into wells of multiwell plates, so that standard multiwell plate well-based assay can be performed without diffusion of the dyes. ${ }^{11)}$ Since the method generates an activity map of bio-samples towards a panel of substrates, we can determine which enzyme(s) contributes to the altered metabolism of a particular substrate. We observed a single spot of fMet-AMCmetabolizing enzyme activity in DEG assay of inflammatory BALF, and its position on the gel was the same as that of APEH in mouse liver lysate. ${ }^{11)}$ This result suggests that APEH activity is increased in inflammatory BALF (Fig. 4a).

For the confirmation, we used the selective inhibitor of APEH to see if the observed activity in BALF was blocked. The activity was completely blocked by AA74-1, a selective APEH inhibitor ${ }^{23}$ (Fig. 4b). The high content of APEH in BALF was further confirmed by Western blotting, which indicated that the APEH content of BALF was dramatically increased in inflammation (Figs. 4c, d). In this condition, cell numbers in BALF also increased as previously reported, ${ }^{14)}$ which was from the infiltration of blood cells to the point of inflammation. Therefore, it seemed that the increased APEH might have reflected the increased cell numbers.

For further mechanistic study, we separately studied the activities in extracellular medium and cellular fraction of BALF separated by centrifugation, and we confirmed that the high APEH activity resided mainly in the cellular fraction of BALF (Fig. 5a). We then performed live cell fluorescence imaging to characterize cellular APEH activities at single cell level. For this purpose, we have developed a fluorogenic substrate based on the 7-amino-4-chloromethylcoumarin scaffold, ${ }^{24)}$ in which the chloromethyl group reacts with intracellular nucleophiles to increase cellular retention. Since the formylmethionyl derivative could not be easily prepared, we used the acetyl-alanine moiety, which was also reported to target $\mathrm{APEH},{ }^{25)}$ as an alternative reactive group. The synthesized probe acetylalanine-7-amino-4-chloromethylcoumarin (AcAlaCMAC) exhibited the desired selectivity toward APEH (Fig. 
(a)

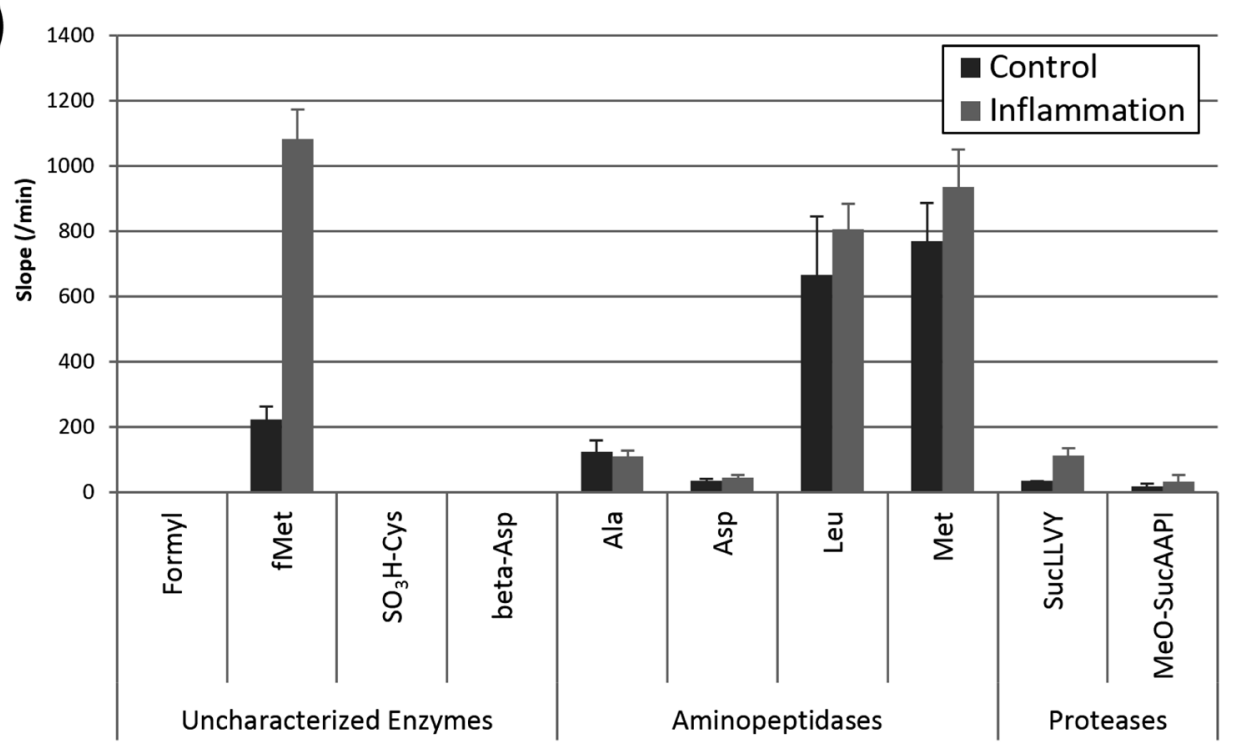

(b)

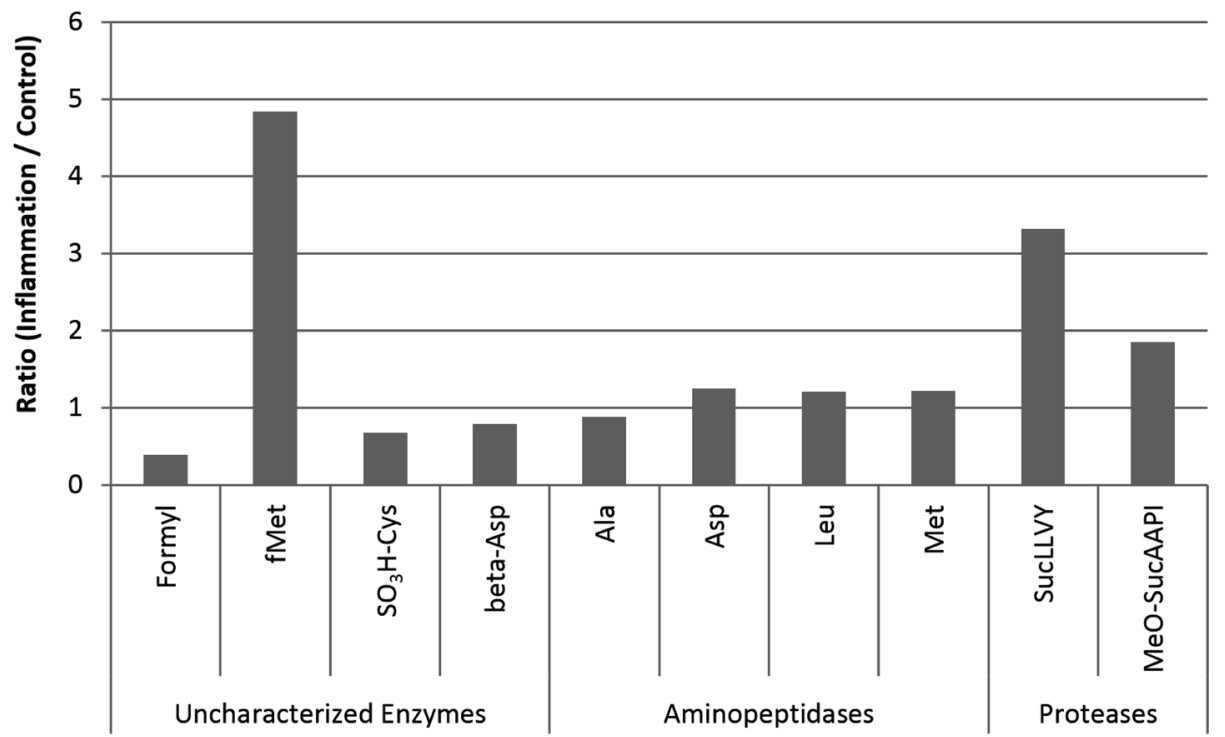

Fig. 3. Reactivities of Fluorogenic Probes in BALF from Inflamed Lung and Control BALF

(a) Fluorescence increase rate of $1 \mu \mathrm{M}$ probe mixed with $1 / 10$-diluted control/inflammatory $\mathrm{BALF}_{\text {in }}$ phosphate buffer (100 $\left.\mathrm{mm}, \mathrm{pH} 7.4\right)$ containing $1 \mathrm{~mm}$ CaCl $\mathrm{L}_{2}$ and $\mathrm{MgCl}_{2}$. Error bars represent S.E. $(n=4)$. (b) Ratio (inflammation/control) of fluorescence increase rate in (a).

5b); the fluorescence increase was completely blocked by APEH-selective inhibitor AA74-1.

As mentioned above, increased numbers of cells were observed in inflammatory BALF and it was confirmed that almost all of them exhibited APEH activity. However, cell-tocell variation of the activity between each cell was not large (Fig. 5c). Thus, it seems likely that the higher APEH activity in BALF was simply reflecting the increase of blood cells, most of which exhibit high APEH activity. These results suggest that APEH activity in BALF might serve as a general biomarker of lung inflammation that leads to infiltration of blood cells. And it could be detected in a simple mix-and-read manner by using fMet-AMC as a substrate. As regards the biological meaning of the increased APEH activity in inflammatory BALF, it seems likely that the enzyme activity is acting as a feedback mechanism to terminate the pro-inflammatory action of formyl peptides. Formyl peptides are mainly derived from infectious pathogens, and they have a potent immune response-triggering activity. ${ }^{26-28)}$ Further, we recently showed that APEH plays a major role in metabolic inactivation of formyl peptides. ${ }^{11)}$ Thus, it is likely that the APEH activity in immune cells contributes to metabolic termination of formylpeptide signaling. Our results demonstrate that APEH is the major enzyme with fMLF-cleaving activity in BALF, and indeed, metabolism of fMLF was much faster in inflammatory BALF than in control BALF (Fig. 6).

Our present findings suggest that the APEH activity in immune cells might determine the duration of inflammation induced by infection with pathogens. In other words, downregulation of APEH activity might result in more prolonged inflammation. In this connection, it is noteworthy that downregulation of APEH activity is reported to be correlated with tumor progression. ${ }^{23,29,30)}$ Further investigation of the relationship between APEH activity and termination of immune 
(a)
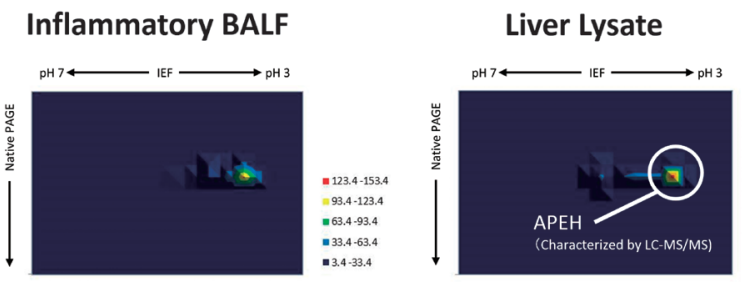

(b)

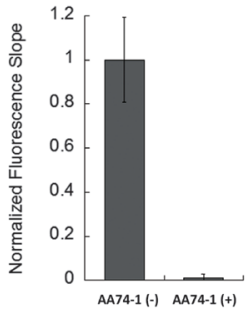

(c)

(d)

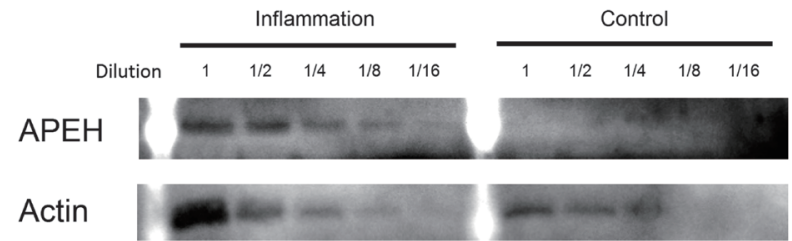

$=0.03 \cdot 0.4$ $=0.3 \cdot 0.3$
$=0.2-0.3$ $=0.1-1.2 .2$ $=0.1-0.1$

\begin{tabular}{|c|c|c|}
\hline & $\begin{array}{c}\text { Cell Number } \\
\left(\times 10^{4} \mathrm{cells} / \mathrm{mL}\right)\end{array}$ & $\begin{array}{c}\text { Protein Concentration } \\
(\mu \mathrm{g} / \mathrm{mL})\end{array}$ \\
\hline $\begin{array}{c}\text { Control } \\
\text { Inflammation }\end{array}$ & $2.8 \pm 0.4$ & $80 \pm 24$ \\
$17.9 \pm 4.2$ & $395 \pm 61$ \\
\hline
\end{tabular}

(a)

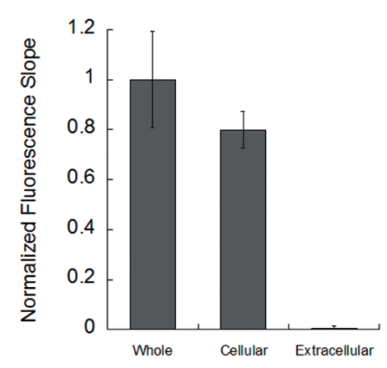

(b)

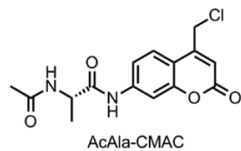

Fig. 4. (a) Result of Diced Electrophoresis Gel (DEG) Assay of Mouse Inflammatory BALF and Liver Lysate; (b) Fluorescence Increase of fMet-AMC in 1/10-Diluted Inflammatory BALF with/without APEH Inhibitor AA74-1; (c) Cell Numbers and Protein Concentrations of Control or Inflammatory BALF; (d) Western Blotting of APEH and Actin in Inflammatory and Control BALF at 1, 1/2, 1/4, 1/8, and 1/16 Dilution

(a) Activity was monitored with fMet-AMC $(10 \mu \mathrm{M})$ substrate in phosphate buffer $\left(100 \mathrm{~mm}, \mathrm{pH}\right.$ 7.4) containing $1 \mathrm{mM} \mathrm{CaCl}_{2}$ and $\mathrm{MgCl}_{2}$. (b) $n=3$. Error bars represent S.D. (c) Protein concentrations were determined using Bradford assay. The value \pm S.D.

\section{responses is ongoing.}

In conclusion, we have shown that APEH is a novel biomarker candidate for lung inflammation, which can be detected in BALF in a simple mix-and-read manner. We also established that high APEH activity in BALF was well correlated with the increased immune cell population. These results support the idea that our enzymomics approach will be a powerful tool for biomarker discovery.

\section{Experimental}

General Materials General chemicals were of the best grade available, supplied by Tokyo Chemical Industries (Japan), Wako Pure Chemical Industries, Ltd. (Japan), Watanabe Chemical Industries (Japan), Sigma-Aldrich (U.S.A.), and Invitrogen (U.S.A.), and were used without further purification. All solvents were used after appropriate distillation or purification.

General Instruments ${ }^{1} \mathrm{H}-\mathrm{NMR}$ spectra were recorded on a JEOL JNM-LA300 instrument. $\delta$ values are in ppm relative to tetramethylsilane (TMS). MS were measured with a JEOL JMS-T100LC AccuTOF electrospray ionization (ESI).

Preparation of $\mathrm{SO}_{3} \mathrm{H}$-AMC 7-Amino-4-methylcoumarin (AMC) $(30 \mathrm{mg}, 0.17 \mathrm{mmol})$ was mixed with Fmoc-L-cysteic acid $\quad(117 \mathrm{mg}, \quad 0.30 \mathrm{mmol}), \quad N, N$-diisopropyl- $N$-ethylamine (DIEA; $180 \mu \mathrm{L}, 1.0 \mathrm{mmol})$ and HATU $(100 \mathrm{mg}, 0.26 \mathrm{mmol})$

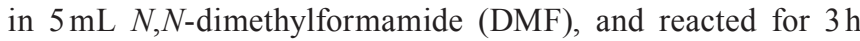
at room temperature. To the solution, piperidine $1 \mathrm{~mL}$ was added, and the solvent was removed in vacuo. The product (c)
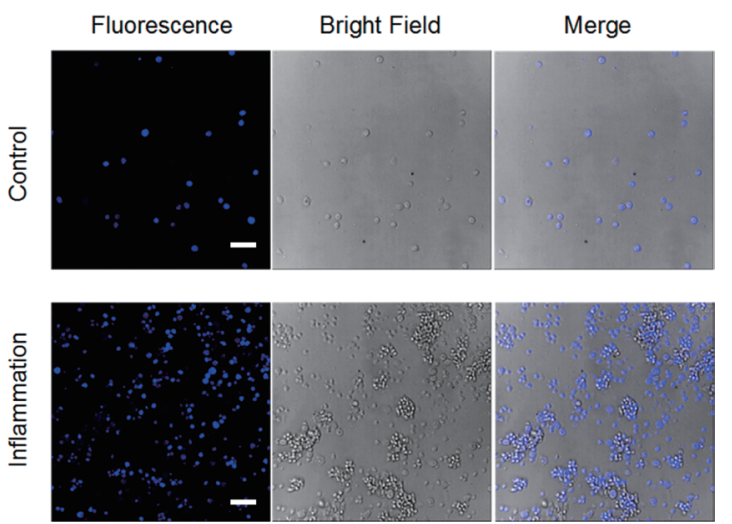

Fig. 5. (a) Fluorescence Increase of fMet-AMC in Whole and Cellular/ Extracellular Compartments of Inflammatory BALF; (b) The Molecular Structure of AcAla-CMAC and Fluorescence Increase of the Molecule after Mixing with $10 \mu \mathrm{g} / \mathrm{mL}$ Mouse Liver Lysate with or without AA74-1 $(100 \mathrm{~nm})$; (c) Fluorescence Images of Inflammatory/Control BALF after Incubation with AcAla-CMAC $(10 \mu \mathrm{M})$

(a) $n=3$. Error bars represent S.D. (c) Scale bar $=50 \mu \mathrm{m}$.

was purified by preparative HPLC $(5.0 \mathrm{mg}$ from $30 \mathrm{mg}$ AMC, yield 9\%). ${ }^{1} \mathrm{H}-\mathrm{NMR}(300 \mathrm{MHz}$, dimethyl sulfoxide (DMSO)$\left.d_{6}\right) \delta: 2.41(\mathrm{~s}, 3 \mathrm{H}), 2.8-3.0(\mathrm{~m}, 1 \mathrm{H}), 3.15(\mathrm{~m}, 1 \mathrm{H}), 4.2-4.3$ $(\mathrm{m}, 1 \mathrm{H}), 6.31(\mathrm{~s}, 1 \mathrm{H}), 7.47(\mathrm{dd}, 1 \mathrm{H}, J=8.7,2.1 \mathrm{~Hz}), 7.76(\mathrm{~m}$, 2H), 8.26 (br, 3H), $11.08(\mathrm{~s}, 1 \mathrm{H})$. High resolution (HR)-MS $\left(\mathrm{ESI}^{+}\right)$: Calcd for $[\mathrm{M}-\mathrm{H}+2 \mathrm{Na}]^{+}$, 371.0298. Found, 371.0310 (+1.2 mms).

Preparation of AcAla-CMAC 7-Amino-4-chloromethylcoumarin (CMAC) was prepared according to the literature. ${ }^{31)}$ Acetylalanine $(240 \mathrm{mg}, 1.8 \mathrm{mmol})$ was dissolved in dichloromethane (DCM; $1 \mathrm{~mL})$ and oxalyl chloride $(200 \mu \mathrm{L}$, $2.4 \mathrm{mmol}$ ) was added dropwise. After addition of one drop of DMF, the mixture was stirred at room temperature for $2 \mathrm{~h}$. CMAC (100 mg, $0.48 \mathrm{mmol}$ ) was dissolved in $1 \mathrm{~mL}$ DMF and $1 \mathrm{~mL}$ DIEA, and then the acid chloride solution was added to the reaction mixture. After $1 \mathrm{~h}$, the solvent was removed in vacuo, and the residue was purified by preparative HPLC to afford AcAla-CMAC (23 mg, yield 14\%). ${ }^{1} \mathrm{H}-\mathrm{NMR}(300 \mathrm{MHz}$, DMSO- $\left.d_{6}\right): 1.18(\mathrm{~d}, 3 \mathrm{H}, J=7.5 \mathrm{~Hz}), 1.86(\mathrm{~s}, 3 \mathrm{H}), 4.40(\mathrm{~m}, 1 \mathrm{H})$, 4.99 (s, 2H), 6.55 (s, 1H), $7.51(\mathrm{dd}, 1 \mathrm{H}, J=8.0,2.1 \mathrm{~Hz}), 7.79$ (d, $1 \mathrm{H}, J=8.0 \mathrm{~Hz}), 7.82(\mathrm{~d}, 1 \mathrm{H}, J=2.1 \mathrm{~Hz}), 8.27(\mathrm{~d}, 1 \mathrm{H}, J=6.6 \mathrm{~Hz})$, $10.50(\mathrm{br}, 1 \mathrm{H}) .{ }^{13} \mathrm{C}-\mathrm{NMR}\left(75 \mathrm{MHz}, \mathrm{DMSO}-d_{6}\right) \delta$ : 17.8, 22.3, $41.2,49.2,105.9,112.3,113.1,115.3,125.8,142.6,150.5$, 154.1, 159.9, 169.2, 172.4. HR-MS $\left(\mathrm{ESI}^{+}\right)$: Calcd for $[\mathrm{M}+\mathrm{Na}]^{+}$, 345.0618. Found, 345.0612 ( $-0.6 \mathrm{mms})$.

Lung Inflammation and BALF Collection Black mice (C57BL/6JJcl, 8 weeks old, male) were anesthetized with pentobarbital, and LPS $(0.012 \mathrm{mg} / \mathrm{mouse})$ or saline was intro- 


\section{(a)}

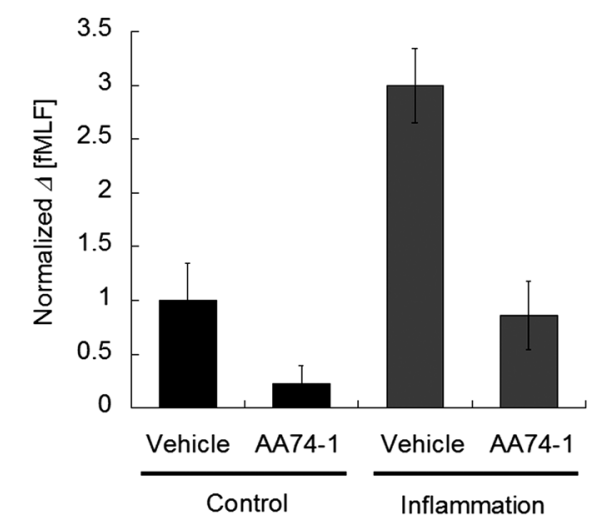

(b)
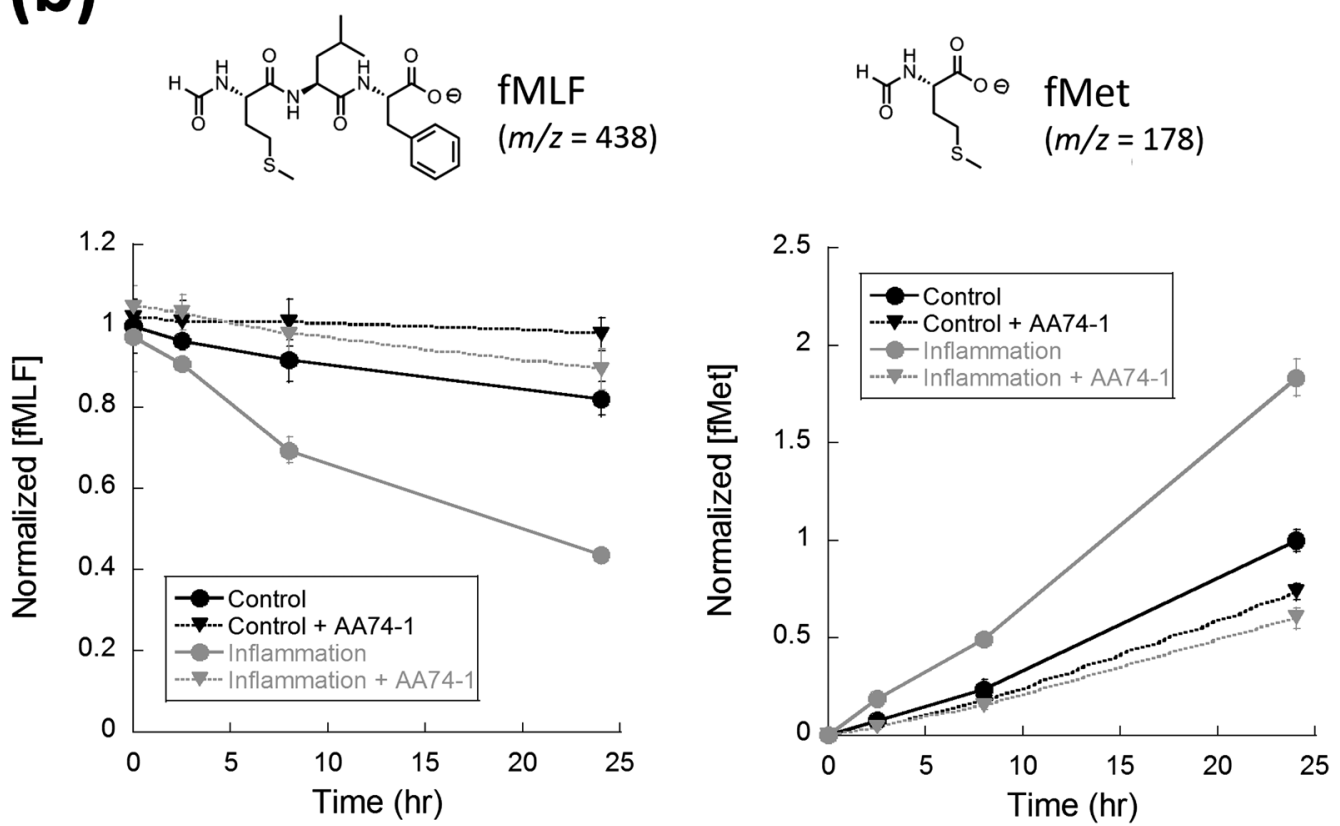

Fig. 6. (a) Quantification of fMLF $(20 \mu \mathrm{M})$ Consumption in the Presence of 1/2-Diluted Inflammatory/Control BALF; (b) Normalized Changes of fMLF (Substrate) and fMet (Product) Mass Intensities Studied by LC-MS-Based Reaction Monitoring

duced via intranasal administration. After one day, mice were anesthetized with pentobarbital, and fMLF $(0.02 \mathrm{mg} / \mathrm{mouse})$ or saline was introduced via intranasal administration. After $3 \mathrm{~h}$, the mice were sacrificed, and an 18-gage catheter was inserted into the trachea. Phosphate buffered saline (PBS) $(0.5 \mathrm{~mL})$ was injected into the lung, and the effluent was collected. The procedure was repeated with $1 \mathrm{~mL}$ PBS, and $0.5 \mathrm{~mL}$ PBS, and the BALF samples collected from each mouse were mixed. After cell counting and protein quantification, BALF was aliquoted, and kept at $-80^{\circ} \mathrm{C}$. Assay was performed with a single aliquot to avoid repeated freeze-thawing. For separation of cellular and extracellular fractions of BALF, freshly prepared BALF was centrifuged at $1500 \mathrm{rpm} \times 5 \mathrm{~min}$, and the supernatant was collected as the extracellular fluid. The pellet was resuspended in a volume of Hank's Balanced Salt Solution (HBSS) equal to that of the supernatant, and the suspension was sonicated on ice with 5 pulses ( $3 \mathrm{~W}$ power; 1 pulse $=1 \mathrm{~s}$ ) from a Sonicator S-4000 (Misonix, U.S.A.). Protein concentrations were determined by Bradford assay.
DEG Assay For two-dimensional DEG assay, isoelectric focusing (IEF; $\mathrm{pH} \mathrm{3-7)} \mathrm{and} \mathrm{native} \mathrm{PAGE} \mathrm{were} \mathrm{performed} \mathrm{as}$ reported. ${ }^{11)}$ In all cases, the size of the electrophoresis gel was $10 \times 10 \mathrm{~cm}$. The diced electrophoresis gel assay was performed according to the literature procedure. ${ }^{11)}$

Fluorometric Assay Fluorescence was read out with a plate reader, EnVision 2103 Multilabel Reader (PerkinElmer, Inc., U.S.A.), under appropriate filter conditions.

Fluorescence Imaging BALF was diluted with an equal amount of HBSS (Gibco) on poly-D-lysine (PDL)-coated glassbottomed dishes (MatTech, Canada), and fluorescence images were taken on a confocal microscope (TCS SP-5; Leica) with appropriate optical conditions.

LC-MS-Based Study of fMLF Metabolism fMLF (final $20 \mu \mathrm{M}$ ) and 2-methyl-4-methoxy-TokyoGreen (internal standard; final $1 \mu \mathrm{M})$ were mixed with BALF (1/2 dilution), and incubated for the indicated times. For inhibitor treatment, lysates were incubated with AA74-1 (final $100 \mathrm{~nm}$ ) for $30 \mathrm{~min}$ for $1.5 \mathrm{~h}$ before the reaction, and an equivalent amount of DMSO 
was added as a vehicle control. The reaction was terminated by adding a 4 -fold excess of $10 \%$ formic acid-methanol, and a $20 \mu \mathrm{L}$ aliquot was injected for LC-MS analysis (Agilent 1200 series/6130 Quadrupole LC/MS) on an InertSustain $\mathrm{C}_{18}$ column (GL Sciences, Japan) under an acidic solvent condition $(0.1 \%$ formic acid) with an increasing gradient of acetonitrile. Detection was performed in the positive mode, and linearity of the signal was confirmed by the use of a reference standard. The decrease of fMLF was determined by analyzing the peak area of chromatograms $(m / z=$ value \pm 0.5$)$ using that of 2-methyl-4-methoxy-TokyoGreen as an internal standard.

Western Blotting After sodium dodecyl sulfate (SDS)PAGE, proteins were transferred onto polyvinylidene difluoride (PVDF) membrane (Bio-Rad, U.S.A.) according to the standard Western blotting protocol. After blocking of the membrane with skim milk, the membrane was incubated in blocking solution containing the first antibody (APEH: Santa Cruz sc-102311; $1 / 500$ dilution/ $\beta$-Actin: Santa Cruz sc-47778; $1 / 1000$ dilution) at $4^{\circ} \mathrm{C}$ for $18 \mathrm{~h}$, washed three times with PBS containing $0.01 \%$ Tween 20 (PBS-T), and incubated in PBS-T containing the second antibody (Sigma-Aldrich A5420; $1 / 2000$ dilution) at room temperature for $2 \mathrm{~h}$. The membrane was washed three times with PBS-T, and chemiluminescence reaction was performed with the use of ECL Prime Western blotting detection reagent (Amersham). Detection was done with an ImageQuant CAS 4000 mini (GE Healthcare, U.S.A.).

Acknowledgments This work was partially supported by the Ministry of Education, Culture, Sports, Science and Technology (MEXT) of Japan (22000006 to T.N., 24689003 and 24659042 to K.H., and 24655147, $15 \mathrm{H} 05371$, and $15 \mathrm{~K} 14937$ to T.K.), Japan Science and Technology Agency (JST) (K.H. and T.K.), and Japan Agency for Medical Research and Development (AMED) (Y.U.). T.K. was supported by Naito Foundation and Mochida Memorial Foundation for Medical and Pharmaceutical Research.

Conflict of Interest The authors declare no conflict of interest.

\section{References}

1) Saghatelian A., Cravatt B. F., Nat. Chem. Biol., 1, 130-142 (2005). 2) Komatsu T., Urano Y., Anal. Sci., 31, 257-265 (2015).

3) Kawaguchi M., Hanaoka K., Komatsu T., Terai T., Nagano T., Bioorg. Med. Chem. Lett., 21, 5088-5091 (2011).

4) Ricci O. E., Tozzi P., Caldini M., Pasquinelli I. T., Orsini B., Ventura L., Borsotti M., Surrenti C., Boll. Soc. Ital. Biol. Sper., 60, 1363-1368 (1984).

5) Amador E., Dorfman L. E., Wacker W. E., Ann. Intern. Med., 62, 30-40 (1965)

6) Goldberg D. M., Martin J. V., Digestion, 12, 232-246 (1975).

7) Cook V. P., Carter N. K., Clin. Chem., 19, 774-776 (1973).
8) Urano Y., Sakabe M., Kosaka N., Ogawa M., Mitsunaga M., Asanuma D., Kamiya M., Young M. R., Nagano T., Choyke P. L., Kobayashi H., Sci. Transl. Med., 3, 110ra119 (2011).

9) Yoshioka K., Komatsu T., Hanaoka K., Ueno T., Terai T., Nagano T., Urano Y., Chem. Commun., 52, 4377-4380 (2016).

10) Yoshioka K., Komatsu T., Nakada A., Onagi J., Kuriki Y., Kawaguchi M., Terai T., Ueno T., Hanaoka K., Nagano T., Urano Y., J. Am. Chem. Soc., 137, 12187-12190 (2015).

11) Komatsu T., Hanaoka K., Adibekian A., Yoshioka K., Terai T., Ueno T., Kawaguchi M., Cravatt B. F., Nagano T., J. Am. Chem. Soc., 135, 6002-6005 (2013).

12) Walsh R. L., Dillon T. J., McLennan G., Clin. Biochem., 25, $263-$ 270 (1992).

13) Ito N., Hirota K., Momoeda K., Iwamori M., Transl. Res., 148, 96-102 (2006).

14) Corteling R., Wyss D., Trifilieff A., BMC Pharmacol., 2, 1 (2002).

15) Gauthier F., Fryksmark U., Ohlsson K., Bieth J. G., Biochim. Biophys. Acta, 700, 178-183 (1982).

16) Ninomiya H., Ichikawa Y., Koga H., Yano T., Oizumi K., Kansenshogaku Zasshi, 65, 672-680 (1991).

17) Gomez D. E., Alonso D. F., Yoshiji H., Thorgeirsson U. P., Eur. J. Cell Biol., 74, 111-122 (1997).

18) Silverman G. A., Bird P. I., Carrell R. W., Church F. C., Coughlin P. B., Gettins P. G., Irving J. A., Lomas D. A., Luke C. J., Moyer R. W., Pemberton P. A., Remold-O’Donnell E., Salvesen G. S., Travis J., Whisstock J. C., J. Biol. Chem., 276, 33293-33296 (2001).

19) Gettins P. G., Chem. Rev., 102, 4751-4804 (2002).

20) Castillo M. J., Nakajima K., Zimmerman M., Powers J. C., Anal. Biochem., 99, 53-64 (1979).

21) Mononen I. T., Kaartinen V. M., Williams J. C., Anal. Biochem., 208, 372-374 (1993)

22) Sheppeck J. E. 2nd, Kar H., Gosink L., Wheatley J. B., Gjerstad E. Loftus S. M., Zubiria A. R., Janc J. W., Bioorg. Med. Chem. Lett., 10, 2639-2642 (2000).

23) Adibekian A., Martin B. R., Wang C., Hsu K. L., Bachovchin D. A. Niessen S., Hoover H., Cravatt B. F., Nat. Chem. Biol., 7, 469-478 (2011).

24) Sebastià J., Cristòfol R., Martín M., Rodríguez Farré E., Sanfeliu C., Cytometry A, 51A, 16-25 (2003).

25) Kiss A. L., Hornung B., Rádi K., Gengeliczki Z., Sztáray B., Juhász T., Szeltner Z., Harmat V., Polgár L., J. Mol. Biol., 368, 509-520 (2007).

26) Pike M. C., Fischer D. G., Koren H. S., Snyderman R., J. Exp. Med., 152, 31-40 (1980).

27) Marasco W. A., Phan S. H., Krutzsch H., Showell H. J., Feltner D. E., Nairn R., Becker E. L., Ward P. A., J. Biol. Chem., 259, 54305439 (1984).

28) Zhang Q., Raoof M., Chen Y., Sumi Y., Sursal T., Junger W., Brohi K., Itagaki K., Hauser C. J., Nature (London), 464, 104-107 (2010).

29) Scaloni A., Jones W., Pospischil M., Sassa S., Schneewind O., Popowicz A. M., Bossa F., Graziano S. L., Manning J. M., J. Lab. Clin. Med., 120, 546-552 (1992).

30) Erlandsson R., Boldog F., Persson B., Zabarovsky E. R., Allikmets R. L., Sümegi J., Klein G., Jörnvall H., Oncogene, 6, 1293-1295 (1991).

31) Oshikawa Y., Ojida A., Chem. Commun., 49, 11373-11375 (2013). 